\title{
MAGE-A9 in head and neck cancer: Prognostic value and preclinical findings in the context of irradiation
}

\author{
TILL J. MEYER ${ }^{1}$, STEFAN HARTMANN ${ }^{1}$, GISELA WOHLLEBEN ${ }^{2}$, MUNA BRISAM $^{1}$, AXEL SEHER ${ }^{1}$, \\ ALEXANDER C. KÜBLER ${ }^{1}$, BÜLENT POLAT ${ }^{2}$ and URS D.A. MÜLLER-RICHTER ${ }^{1}$ \\ ${ }^{1}$ Department of Oral and Maxillofacial Plastic Surgery, University Hospital of Würzburg, D-97070 Würzburg; \\ ${ }^{2}$ Department of Radiation Oncology, University Hospital of Würzburg, D-97080 Würzburg, Germany
}

Received September 14, 2017; Accepted December 8, 2017

DOI: $10.3892 /$ mco.2018.1558

\begin{abstract}
Radiotherapy alone, or as an addition to surgery is important for the treatment of head and neck squamous cell carcinoma (HNSCC). In addition to their expression in germ cells, melanoma associated antigens-A (MAGE-A) are only expressed in malignant tissue. Notably, there is a known correlation between MAGE-A9 expression and poor prognosis in HNSCC patients. However, current knowledge regarding the function of MAGE-A9 expression, particularly in the context of irradiation, is limited. MAGE-A9 expression in 37 oral squamous cell carcinoma patents was immunohistochemically determined and analyzed for overall survival by the Kaplan-Meier log-rank test. Next, the expression of MAGE-A9 was determined by reverse transcription-quantitative polymerase chain reaction in HNSCC cell lines prior to and following irradiation with 2 Gray. The radiosensitivity of each cell line was determined using a clonogenic survival assay. There was a significantly $(\mathrm{P}=0.0468)$ longer overall survival in patients with a low level of MAGE-A9 expression. The median overall survival in patients with high MAGE-A9 expression was $47 \%$ compared to $73 \%$ in the group with low MAGE-A9 expression. The cell lines revealed a distinct expression pattern of MAGE-A9. Following irradiation of the cell lines, a significant enhancement of MAGE-A9 mRNA expression levels
\end{abstract}

Correspondence to: Dr Till J. Meyer, Department of Oral and Maxillofacial Plastic Surgery, University Hospital of Würzburg, Pleicherwall 2, D-97070 Würzburg, Germany

E-mail: meyer_t2@ukw.de

Abbreviations: MAGE-A, melanoma associated antigen-A; UICC, union for international cancer control; IRS, immunoreactive score; SI, amount of staining; PP, number of positive cells; SF2, surviving fraction at $2 \mathrm{~Gy} ; \mathrm{D}_{10}$, dose in Gy for gaining SF10; SC, standardized coefficient; NY-ESO-1, New York oesophageal squamous cell carcinoma-1

Key words: MAGE-A9, melanoma-associated antigens-A, radiotherapy, irradiation, head and neck cancer, head and neck squamous cell carcinoma was observed. The most prominent alteration in MAGE-A9 expression was observed in the most radioresistant cell line. A high MAGE-A9 expression level correlates significantly with lower overall survival in HNSCC patients. Additionally, irradiation increased the MAGE-A9 mRNA levels in all five HNSCC cell lines, and the most resistant cell line demonstrated the greatest increase in MAGE-A9 expression following irradiation.

\section{Introduction}

Approximately 690,000 new cases of head and neck cancer (including oral cavity, lip, nasopharynx, other pharynx and larynx) were reported worldwide in 2012. Head and neck cancers represent approximately $4.8 \%$ of all cancer cases (1). The cumulative overall 5-year survival remains poor at approximately $50 \%$ (2). The improvement observed in the last decade in head and neck cancer survival may be due to a higher incidence of human papilloma virus associated head and neck cancer rather than to more effective therapy $(3,4)$.

Radiation therapy is an important part of head and neck cancer therapy. Radiotherapy is used in addition to surgical treatment (neoadjuvant or adjuvant) or as the primary treatment, often in combination with chemotherapy $(5,6)$.

Melanoma-associated antigens-A (MAGE-A) are a part of the cancer/testis antigen (CTA) family (7). Recognized by T-cells, the MAGE-A proteins are a promising target for cancer immunotherapy and cancer vaccination (8-10). Expression of MAGE-A has been found in stem cells, placentae, ovaries, testes $(7,11)$ and malignancies, such as bronchial carcinoma, malignant melanoma, breast cancer, urothelial carcinoma, prostate cancer and head and neck cancer (12). Notably, MAGE-A expression is found in leukoplakia with dysplasia, or carcinoma in situ but not in ulcers, lichen planus or leukoplakia without dysplasia (13). MAGE-A tumor antigens are frequently expressed in head and neck squamous cell carcinoma (HNSCC) primary tumors, recurrent tumors as well as in lymph node metastasis (14). High expression levels of MAGE-A in HNSCC tumors are predictive for a poor overall survival $(15,16)$. The correlation between the expression of a particular MAGE-A subgroup and the treatment efficiency of chemotherapeutic 
drugs was reported by our group earlier (17-19). Han et al showed that there is a significant correlation between high MAGE-A9 expression levels and a low overall survival in laryngeal squamous cell carcinoma patients (20). Similar findings were reported for hepatocellular and renal cell carcinoma as well as breast, ovarian, lung and colorectal cancer (21-26).

Because radiotherapy is the backbone of non-surgical treatment and is often used in addition to surgical treatment for head and neck cancer, an investigation of MAGE-A9 expression in this context is crucial.

Thus, the present study was designed to address the following two important aspects: First, to investigate the prognostic value of MAGE-A9 expression in HNSCC patients, and, second, analyse the influence of irradiation on MAGE-A9 expression to obtain a more detailed understanding of the interactions between irradiation and MAGE-A9 as a potential marker of radioresistance.

\section{Materials and methods}

Data collection. Paraffin-embedded head and neck squamous cell carcinoma (HNSCC) tissue samples were collected from the archives of the Department of Pathology at the University of Würzburg. All samples with follow-up data of at least a year were included in our study. The tumour sites were located on the tongue, lip, tonsil, cheek, palate, and oropharynx.

This study was approved by the Ethics Committee of the University of Würzburg; the reference number is 2016050801.

Immunohistochemical staining of MAGE-A9. MAGE-A9 expression levels in all tissue samples were analysed by immunohistochemical staining with the MAGE-A9 antibody (sc-130811; Santa Cruz Biotechnology, Inc., Dallas, TX, USA) diluted to a concentration of 1:10. The detection was performed using the DAKO Advance+ detection system (DakoCytomation, Pathology Products Dako Deutschland $\mathrm{GmbH}$, Hamburg, Germany) with DAB as the chromogen. Hematoxylin was used for counterstaining. The staining intensity was analysed by using the immunoreactive score (IRS) of Remmele and Steger (27). The immunoreactive score (IRS) was calculated as the product of the amount of staining (SI) (0: No reaction; 1 : Weak reaction; 2 : Moderately high reaction; 3: Strong reaction) and the number of positive cells (PP) (0: Negative; $1:<10 \%$ positive cells; $2: 10-50 \%$ positive cells; 3: $21-80 \%$ positive cells; $4:>80 \%$ positive cells) (27). The mean IRS was calculated, and patients with an IRS below the mean were considered 'MAGE-A9 low', and the others were considered 'MAGE-A9 high'.

Cell lines. The cell lines were cultured in an atmosphere of $5 \% \mathrm{CO}_{2} / 95 \%$ air at $37^{\circ} \mathrm{C}$. We split the cells two to three times per week. All cell lines were isolated from male patients at the Cancer Institute of the University of Pittsburgh (28) (for details see Table I). The cells were cultured in a low-glucose DMEM medium (Gibco, Carlsbad, USA) supplemented with $10 \%$ foetal bovine serum (Gibco, Carlsbad, USA), $2 \mathrm{mM}$ L-Glutamine (Biochrom, Berlin, Germany) and 1\% Pen/Strep (Promocell, Heidelberg, Germany).
Irradiation. For the X-irradiation, a $6 \mathrm{MV}$ Siemens linear accelerator (Siemens, Concord, CA, USA) was used at a dose rate of $2 \mathrm{~Gy} / \mathrm{min}$.

RNA isolation and reverse transcription-quantitative polymerase chain reaction ( $R T-q P C R)$. After separating the cells from the culture plate, RNA isolation was performed using the TRIzol reagent (Ambion, Carlsbad, CA, USA). The RNA concentration was measured using a Nano Drop 2000 (Thermo Fisher Scientific, Waltham, MA, USA). The RNA concentration was determined at a wavelength of $260 \mathrm{~nm}$, using fully desalinated water as the blank. All samples were adjusted to a concentration of $0.2 \mu \mathrm{g}$ RNA $/ \mathrm{ml}$.

Reverse transcription was performed in two steps. In the first step, the samples were cleaned of DNA contamination using a gDNA Wipeout Buffer (Qiagen, Venlo, the Netherlands), by heating to $42^{\circ} \mathrm{C}$ for $2 \mathrm{~min}$ and then cooling on ice. In the second step, the reverse transcription was performed using the QuantiTect Reverse Transcription kit (Qiagen). The incubation temperature was $42^{\circ} \mathrm{C}$ for $15 \mathrm{~min}$, and the denaturation temperature was $95^{\circ} \mathrm{C}$ for $3 \mathrm{~min}$. The detailed compositions of the reverse transcription reactions, step 1 and 2 are shown in the Tables II and III.

PCR was performed using a QuantiTect SYBR-Green PCR kit 200, QuantiTect Primer Assays (MAGE-A9: Hs_MAGEA9_1_SG, QT00230874 and $\beta$-actin: Hs_ACTB _2_SG, QT0168047) (all from Qiagen) and a C1000 Thermal Cycler (Bio-Rad, Hercules, CA, USA). The composition of the PCR and the PCR cycling conditions are provided in the Tables IV and V. The quantitative expression levels of the tested genes were calculated as a ratio to the expression level of $\beta$-actin.

Cells were plated in Petri dishes $24 \mathrm{~h}$ before irradiation with a dose of $2 \mathrm{~Gy}$. Cells were harvested, and RNA was isolated 24 and $48 \mathrm{~h}$ after irradiation. Non-irradiated cells were used as controls.

Clonogenic survival assay. Cell survival was analysed using a clonogenic survival assay. The number of irradiated cells plated in Petri dishes depended on the radiation dose and the cell line. The irradiated cells were cultured in a humidified atmosphere $\left(5 \% \mathrm{CO}_{2}\right.$ at $\left.37^{\circ} \mathrm{C}\right)$ for two weeks. At the end of the two weeks, the cells were fixed using methanol and acetic acid in a ratio of 3:1 and stained using $0.1 \%$ crystal violet. All colonies consisting of $>50$ cells were included for analysis.

The mean survival data were fitted to the following linear quadratic (LQ) model: $S F=\exp (-\alpha \mathrm{X}-\beta \mathrm{X} 2)$, where $\mathrm{SF}$ is the survival fraction, $X$ is the irradiation dose, and $\alpha$ and $\beta$ are the fitted parameters.

Statistics. All statistical calculations were carried out using GraphPad PRISM 6.04 (GraphPad Software, Inc., La Jolla, CA, USA). Comparisons of clinical parameters between the MAGE-A9 high and low group were carried out by an unpaired t test.

The tumour samples were allocated to a group with either a lower or a higher level of MAGE-A9 expression compared to the median level. The overall survival of the patients in the two groups was compared using a Kaplan-Meier plot with a log-rank test. 
Table I. Names, origin, TNM-classification and grading of the cell lines.

\begin{tabular}{lllc}
\hline Cell line & \multicolumn{1}{c}{ Origin } & $\begin{array}{c}\text { TNM- } \\
\text { classification }\end{array}$ & Grading \\
\hline PCI 1-1 & Larynx (glottis) & pT2 N0 M0 & G2 \\
PCI 9-1 & Base of tongue & pT4 N3 M0 & G2 \\
PCI 13-1 & Retromolar triangle & pT4 pN1 M0 & G3 \\
PCI 52 & Aryepiglottic fold & pT2 N0 M0 & G2 \\
PCI 68-1 & Tongue & pT4 N0 M0 & G1 \\
\hline
\end{tabular}

Table II. Composition reverse transcription step 1.

\begin{tabular}{ll} 
gDNA Wipeout buffer, 7X & $2 \mu 1$ \\
\hline Template RNA & $5 \mu 1$ \\
RNase-free water & $7 \mu 1$ \\
\hline
\end{tabular}

Table III. Composition reverse transcription step 2.

\begin{tabular}{lr}
\hline Quantiscript reverse transcriptase & $1 \mu 1$ \\
\hline Quantiscript RT buffer, 5X & $4 \mu 1$ \\
RT primer mix & $1 \mu 1$ \\
Purified RNA sample & $14 \mu 1$ \\
\hline
\end{tabular}

Table IV. Composition of PCR.

\begin{tabular}{ll}
\hline SYBR-Green Master mix & $12.5 \mu 1$ \\
\hline Quantitect primer assay & $2.75 \mu 1$ \\
cDNA & $2.5 \mu 1$ \\
$\mathrm{H}_{2} \mathrm{O}$ & $7.25 \mu 1$ \\
\hline
\end{tabular}

Table V. PCR protocol.

\begin{tabular}{clcc}
\hline Repeats & \multicolumn{1}{c}{ PCR-step } & Duration & Temperature \\
\hline x1 & Polymerase activation & $15 \mathrm{~min}$ & $95^{\circ} \mathrm{C}$ \\
x40 & Denaturation & $15 \mathrm{sec}$ & $94^{\circ} \mathrm{C}$ \\
x40 & Annealing & $30 \mathrm{sec}$ & $50-60^{\circ} \mathrm{C}$ \\
x40 & Elongation & $30 \mathrm{sec}$ & $72^{\circ} \mathrm{C}$ \\
x40 & Read data & & \\
\hline
\end{tabular}

We analysed the impact of the irradiation dose (2 Gy) on the MAGE-A9-fold change with the use of a Wilcoxon matched-pairs signed rank test. The correlation between the clonogenic cell survival and the expression of MAGE-A9 subgroups was determined using linear regression. A P-value $<0.05$ was considered significant.

\section{Results}

Patient data. We included a total of 37 patients in this retrospective analysis. Based on their MAGE-A9 IRS, 19 patients were assigned to the 'MAGE-A9 high' group, and 18 patients were assigned to the 'MAGE-A9 low' group. The mean age was 57.88 years $(\mathrm{SD} \pm 11.20)$ in the MAGE-A9 high group and 55.92 years $(\mathrm{SD} \pm 11.51)$ in the MAGE-A9 low group. The mean Union for International Cancer Control (UICC) stage was $2.765(\mathrm{SD} \pm 1.251)$ and $2.706(\mathrm{SD} \pm 0.9852)$ for MAGE-A9 high and MAGE-A9 low, respectively. The mean T stage was $2.588(\mathrm{SD} \pm 1.176)$ in the high expression group and 2.471 $(\mathrm{SD} \pm 1.068)$ in the low expression group. The mean $\mathrm{N}$ stage was $0.5625(\mathrm{SD} \pm 0.8921)$ for the high expression group and 0.6000 ( $\mathrm{SD} \pm 0.7368$ ) for the low expression group. None of these parameters showed significant differences between the two groups (age $\mathrm{P}=0.6033$; UICC $\mathrm{P}=0.8800$; $\mathrm{T}$ stage $\mathrm{P}=0.7620 ; \mathrm{N}$ stage $\mathrm{P}=0.8991$ ) (Fig. 1). For three patients, data on the UICC stage, $\mathrm{T}$ stage and $\mathrm{N}$ stage were not available (two in the MAGE-A9 low group, one in the MAGE-A9 high group).

MAGE-A9 expression is correlated with a shorter overall survival. Patient survival was significantly $(\mathrm{P}=0.0468)$ longer in the group with low MAGE-A9 expression compared to the group with high MAGE-A9 expression (Fig. 2). The surviving fraction after 5 years was $47.4 \%$ for the high MAGE-A9 expression group and $73.7 \%$ for the low expression group.

Radiosensitivity is different in the cell lines. Cell line-specific survival after treatment with radiotherapy was measured with a clonogenic survival assay. As shown in Table VI, there were distinct differences in the cell line-specific survival among the investigated cell lines. Measuring the survival fraction after radiation with 2 Gy (SF2), the cell line PCI 9-1 had the lowest SF2 (SF2=0.184), and the cell line PCI 68-1 had the highest SF2 (SF2=0.479) (Table VI). Intermediate SF2s were determined for the cell lines PCI 13-1 (SF2=0.421), PCI 52 $(\mathrm{SF} 2=0.349)$ and PCI 1-1 (SF2=0.239). In addition, a calculation of the radiation dose, which was necessary to achieve a surviving fraction of $0.1\left(D_{10}\right)$, suggests that the PCI 9-1 cell line was the most radiosensitive cell line $\left(D_{10}=2.693 \mathrm{~Gy}\right)$, and the PCI 68-1 cell line was the most radioresistant cell line $\left(\mathrm{D}_{10}=5.745 \mathrm{~Gy}\right)$ (Table VI). Similar to the SF2 measurements, the second highest $\mathrm{D}_{10}$ was observed in the cell line PCI 13-1 $\left(\mathrm{D}_{10}=4.533 \mathrm{~Gy}\right)$, the third highest in the cell line PCI $52\left(D_{10}=3.998 \mathrm{~Gy}\right)$ and the second lowest in the cell line PCI 1-1 $\left(\mathrm{D}_{10}=3.228 \mathrm{~Gy}\right)$, as shown in Table VI.

Irradiation induces MAGE-A9 expression. We next analysed the fold-change of MAGE-A9 expression by RT-PCR in relation to the non-irradiated control cells, adjusted to the housekeeping gene $\beta$-actin. After $24 \mathrm{~h}$, the average MAGE-A9 expression was increased by 1.31 (PCI 1-1: 1.74; PCI 9-1: 1.12; PCI 13-1: 0.43; PCI 52: 1.00; PCI 68-1: 2.24); however, this fold-change was not significantly different from that of the non-irradiated controls $(\mathrm{P}=0.3125)$. After $48 \mathrm{~h}$, the average MAGE-A9 expression was increased by 4.08 -fold compared to the non-irradiated controls (PCI 1-1: 3.24; PCI 9-1: 1.95; PCI 13-1: 1.63; PCI 52: 

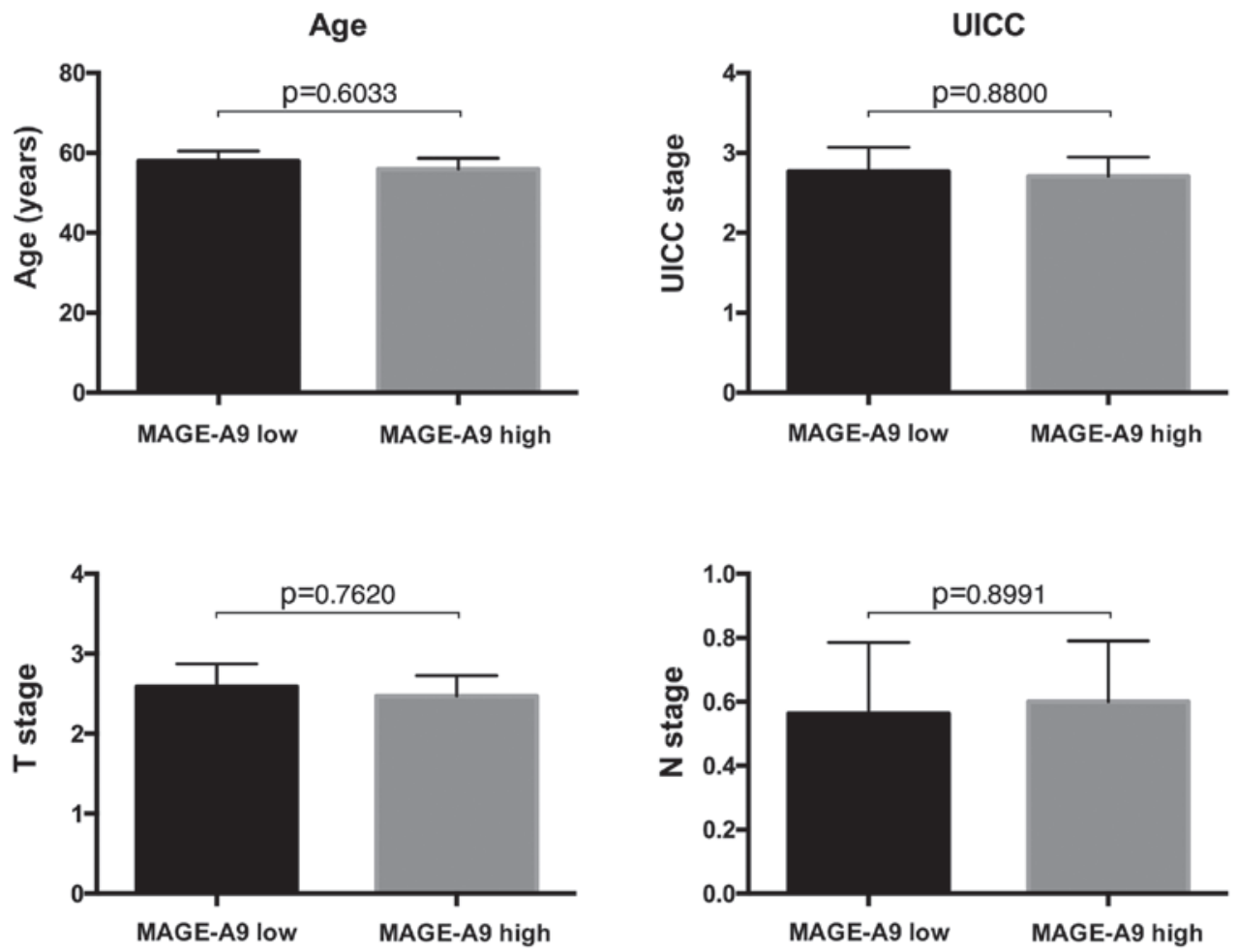

Figure 1. Patient data in both groups shows balanced cohorts for MAGE-A9 high and MAGE-A9 low. MAGE, melanoma associated antigens.

1.62; PCI 68-1: 11.95). Compared to the non-irradiated controls, the enhancement of MAGE-A9 expression was statistically significant $(\mathrm{P}=0.0313)$ (Fig. 3). Additionally, the fold-change of MAGE-A9 expression was time-dependent as we observed an increase in the expression level of all of the cell lines from the $24 \mathrm{~h}$ measurements to the $48 \mathrm{~h}$ measurements. Based on a Wilcoxon matched-pairs signed rank test, this finding is also statistically significant $(\mathrm{P}=0.0313)$.

Importantly, the most prominent fold-change of MAGE-A9 expression was observed in the PCI 68-1 cell line (24 h after irradiation: 2.24, $48 \mathrm{~h}$ after irradiation: 11.95). Based on the clonogenic assay, the PCI 68-1 cell line was also the most radioresistant cell line $\left(D_{10}=5.75 \mathrm{~Gy}\right)$. However, the correlation between MAGE-A9-fold change and radiosensitivity of the five investigated cell lines was not statistically significant $\left(\mathrm{R}^{2}=0.5648, \mathrm{P}=0.1430\right)$ but showed a trend.

\section{Discussion}

To the best of our knowledge, we are the first to report on irradiation and MAGE-A9 expression in head and neck cancer cells. We show a correlation between poor overall survival and MAGE-A9 expression in a cohort of head and neck cancer patients. Furthermore, we provide evidence that MAGE-A9 mRNA expression is induced by irradiation. This effect is time-dependent and significant. The most radioresistant cell line showed the most prominent increase in MAGE-A9 expression; however, linear regression analysis did not show a statistically significant correlation between MAGE-A9 induction and radiosensitivity for any tested cell line.

Adjuvant radiotherapy in addition to surgery is an essential element of therapy for closed or positive margin

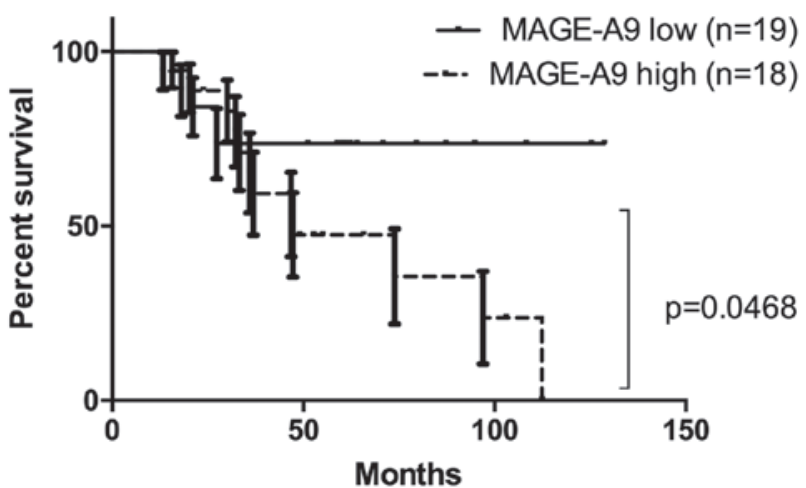

Figure 2. Overall survival of patients with a low vs. a high level of MAGE-A9-tumour expression. By the immunohistochemical grade of MAGE-A9 expression, the patients were divided to a group of low $(n=19)$ or high ( $\mathrm{n}=18)$ MAGE-A9 expression. The overall survival is significantly $(\mathrm{P}=0.0468)$ lower in the group with a high level of MAGE-A9 expression. The surviving fraction at five years was $73.7 \%$ for the MAGE-A9 low group and $47.4 \%$ for the MAGE-A9 high group. MAGE, melanoma associated antigens.

and/or nodal positive HNSCC to improve locoregional tumour control $(5,29,30)$. Primary radiotherapy is a potentially curative option in surgical unresectable HNSCC, often in combination with radiosensitizing chemotherapy (6). Both adjuvant and primary radiotherapies have a positive influence on disease eradication and overall patient survival $(5,6,29,30)$.

The nearly exclusive expression of the MAGE-A family members in malignancies makes them an interesting subject for cancer research $(16,13,31)$. As shown by Figueiredo et al, MAGE-A tumour antigens are frequently expressed in HNSCC (31). Simultaneous cytoplasmic and nuclear protein expression of MAGE-A has been identified as an independent marker for poor survival in HNSCC patients (15). Compared 
Table VI. Mean value of the surviving fraction (SF) after irradiation with 2 Gy, D10 (Gy), $\alpha(G y-1)$ and $\beta(G y-2)$.

\begin{tabular}{lccrr}
\hline Cell line & SF2 & D10 (Gy) & $\alpha(\mathrm{Gy}-1)$ & $\beta(\mathrm{Gy}-2)$ \\
\hline PCI 1-1 & $0.239 \pm 0.010$ & 3.228 & $0.311 \pm 0.011$ & $1.4 \mathrm{E}-15 \pm 0.003$ \\
PCI 9-1 & $0.184 \pm 0.017$ & 2.693 & $0.357 \pm 0.030$ & $0.005 \pm 0.006$ \\
PCI 13-1 & $0.421 \pm 0.029$ & 4.533 & $0.162 \pm 0.021$ & $0.013 \pm 0.004$ \\
PCI 52 & $0.349 \pm 0.058$ & 3.998 & $0.207 \pm 0.059$ & $0.011 \pm 0.014$ \\
PCI 68-1 & $0.479 \pm 0.034$ & 5.745 & $0.152 \pm 0.021$ & $0.004 \pm 0.003$ \\
\hline
\end{tabular}

to cancer/testis antigens, e.g., New York oesophageal squamous cell carcinoma-1 (NY-ESO-1), MAGE-A antigens are significantly more often expressed in epithelial cancers (123 (3.4\%) vs. 815 (22.2\%) of 3668 epithelial cancer cases), particular in HNSCC (6 (3.8\%) vs. 71 (41.7\%) of 158 HNSCC cases) (32). MAGE-A1-6 expression in patients' sputum correlated with higher incidences of a second primary cancer and poor oncologic outcome in larynx and hypopharynx squamous cell carcinoma patients (33), and high MAGE-A expression levels are correlated with malignant transformation of oral leukoplakia (34).

Recently, it has been shown that MAGE-A9 expression in laryngeal, hepatocellular and renal cell carcinoma, as well as in breast, ovarian, lung and colorectal cancer, is a negative prognostic marker (20-26). Based on our patient cohort, we can confirm a significant correlation $(\mathrm{P}=0.0468)$ between high MAGE-A9 expression levels and lower overall patient survival. Importantly, both groups were well balanced in terms of age, UICC stage, $\mathrm{T}$ stage and $\mathrm{N}$ stage. These parameters are well-known confounds of overall survival in head and neck cancer patient cohorts. One limitation of our study is that patients' HPV status was unknown. However, the age of approximately 60 years, high $\mathrm{T}$ stage and low $\mathrm{N}$ stage indicate a more classical, HPV-negative cohort. Additionally, the tissue collection was performed approximately 15 years prior to this study, when the rate of HPV-related HNSCC was lower.

There are only a few studies concerning the role of MAGE-A expression in cancer cells. Various groups have reported on the direct and indirect inhibitory effects of MAGE-A proteins on the function of the tumour suppressor p53 (35-37), suggesting a role of MAGE-A proteins in DNA damage response. Recently the effect of MAGE-A11 expression on cisplatin resistance in HNSCC cells could be shown (38).

The results of the qPCR showed a clear and time-dependent increase of MAGE-A9 mRNA expression after irradiation with 2 Gy. Interestingly, Picard et al observed an induction of MAGE-A9 expression in bladder cancer cells after treatment with chemotherapeutic drugs as the methylation inhibitor 5-AZA-DC was induced (39). A further upregulation of MAGE-A9 expression was observed by co-incubation of the deacetylase inhibitors MS-275 and 4-phenylbutyrate together with 5-AZA-DC but not with either agent alone (39). The gene silencing by promoter hypermethylation and histone deacetylation were shown for the subgroups MAGE-A1, MAGE-A2, MAGE-A3 and MAGE-A12 in different human cancer cells (40).

Cacan et al showed that irradiation with 5 Gy increases the histone acetylation in colorectal cancer cells (41). It could be

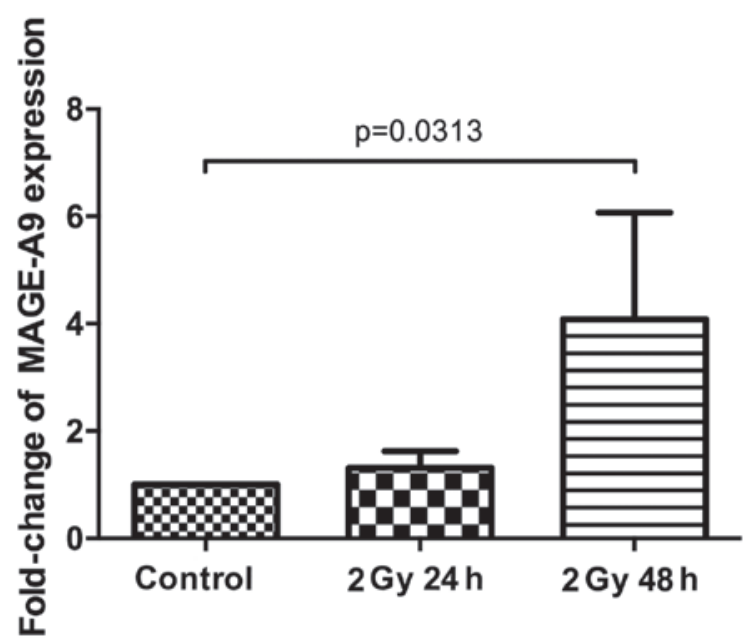

Figure 3. Fold-change of MAGE-A9 after irradiation. After irradiation of five HNSCC cell lines with a dose of 2 Gy, the MAGE-A9 expression was analysed by RT-PCR. $48 \mathrm{~h}$ after irradiation there was a statistically significant increase in the MAGE-A9 mRNA level in relation to $\beta$-actin. HNSCC, head and neck squamous cell carcinoma; MAGE, melanoma associated antigens.

hypothesized that the irradiation-induced histone acetylation causes MAGE-A9 upregulation after irradiation. Based on The Cancer Genome Atlas data, MAGE-A9 copy number gain or amplification is highly significantly correlated with Rac1 gain or amplification $(\mathrm{P}<0.001)$. Racl is one of the key proteins responsible for cancer cell motility and tissue invasion while interacting for example with the cytoskeletal protein lamellipodium. Additionally, the co-occurrence of alterations in MAGE-A9 and Rac1 is highly significantly associated with poorer overall survival (median survival in the altered group: 35.45 months; in the unaltered group: 67.81 months; $\mathrm{P}=0.00299)$ in HNSCC $(42,43)$. Racl is a known factor contributing to chemoresistance and radioresistance, particularly in HNSCC (44-46).

Our findings provide evidence for a link between irradiation and MAGE-A9 expression. Because irradiation is a major treatment in head and neck cancer, and given that MAGE-A9 expression has been shown to be a marker of a worse prognosis in several tumor entities, including head and neck cancer, this link warrants further investigation.

MAGE-A9 protein could be an interesting candidate to become part of a biomarker panel for personalized therapy, because of the prognostic characteristics and the potential role as a target protein.

High MAGE-A9 expression levels correlated significantly with shorter patient survival in head and neck 
squamous cell carcinoma patients. MAGE-A9 mRNA levels were significantly elevated by irradiation with 2 Gy in five head and neck squamous cell carcinoma cell lines. The most prominent fold-change in MAGE-A9 expression was observed in the most radioresistant cell line. Thus, MAGE-A9 may play a role in radioresistance in head and neck cancer.

\section{Acknowledgements}

Language editing support was provided by the American Journal Experts (AJE). The present study was supported by the Interdisciplinary Center for Clinical Research Würzburg (IZKF Würzburg, to S. Hartmann).

\section{Competing interests}

The authors declare that they have no competing interests.'

\section{References}

1. Ferlay J, Soerjomataram I, Dikshit R, Eser S, Mathers C, Rebelo M, Parkin DM, Forman D and Bray F: Cancer incidence and mortality worldwide: Sources, methods and major patterns in GLOBOCAN 2012. Int J Cancer 136: E359-E386, 2015.

2. Gupta S, Kong W, Peng Y, Miao Q and Mackillop WJ: Temporal trends in the incidence and survival of cancers of the upper aerodigestive tract in Ontario and the United States. Int $\mathbf{J}$ Cancer 125: 2159-2165, 2009.

3. Pulte D and Brenner H: Changes in survival in head and neck cancers in the late 20th and early 21 st century: A period analysis. Oncologist 15: 994-1001, 2010.

4. Fakhry C, Westra WH, Li S, Cmelak A, Ridge JA, Pinto H, Forastiere A and Gillison ML: Improved survival of patients with human papillomavirus-positive head and neck squamous cell carcinoma in a prospective clinical trial. J Natl Cancer Inst 100: 261-269, 2008

5. Zelefsky MJ, Harrison LB, Fass DE, Armstrong JG, Shah JP and Strong EW: Postoperative radiation therapy for squamous cell carcinomas of the oral cavity and oropharynx: Impact of therapy on patients with positive surgical margins. Int J Radiat Oncol Biol Phys 25: 17-21, 1993.

6. Adelstein DJ, Li Y, Adams GL, Wagner H Jr, Kish JA, Ensley JF, Schuller DE and Forastiere AA: An intergroup phase III comparison of standard radiation therapy and two schedules of concurrent chemoradiotherapy in patients with unresectable squamous cell head and neck cancer. J Clin Oncol 21: 92-98, 2003

7. Scanlan MJ, Simpson AJ and Old LJ: The cancer/testis genes: Review, standardization, and commentary. Cancer Immun 4: 1, 2004.

8. Sang M, Lian Y, Zhou X and Shan B: MAGE-A family: Attractive targets for cancer immunotherapy. Vaccine 29 8496-8500, 2011.

9. Scanlan MJ, Gure AO, Jungbluth AA, Old LJ and Chen YT: Cancer/testis antigens: An expanding family of targets for cancer immunotherapy. Immunol Rev 188: 22-32, 2002.

10. Atanackovic D, Altorki NK, Stockert E, Williamson B, Jungbluth AA, Ritter E, Santiago D, Ferrara CA, Matsuo M, Selvakumar A, et al: Vaccine-induced CD4+ T cell responses to MAGE-3 protein in lung cancer patients. J Immunol 172: 3289-3296, 2004.

11. Müller-Richter UD, Dowejko A, Zhou W, Reichert TE and Driemel O: Different expression of MAGE-A-antigens in foetal and adult keratinocyte cell lines. Oral Oncol 44: 628-633, 2008.

12. Sang M, Wang L, Ding C, Zhou X, Wang B, Wang L, Lian Y and Shan B: Melanoma-associated antigen genes-an update. Cancer Lett 302: 85-90, 2011.

13. Krauss E, Rauthe S, Gattenlöhner S, Reuther T, Kochel M, Kriegebaum U, Kübler AC and Müller-Richter UD: MAGE-A antigens in lesions of the oral mucosa. Clin Oral Investig 15: 315-320, 2011
14. Laban S, Giebel G, Klümper N, Schröck A, Doescher J, Spagnoli G, Thierauf J, Theodoraki MN, Remark R, Gnjatic S, et al: MAGE expression in head and neck squamous cell carcinoma primary tumors, lymph node metastases and respective recurrences-implications for immunotherapy. Oncotarget 8: 14719-14735, 2017.

15. Laban S, Atanackovic D, Luetkens T, Knecht R, Busch CJ, Freytag M, Spagnoli G, Ritter G, Hoffmann TK, Knuth A, et al: Simultaneous cytoplasmic and nuclear protein expression of melanoma antigen-A family and NY-ESO-1 cancer-testis antigens represents an independent marker for poor survival in head and neck cancer. Int J Cancer 135: 1142-1152, 2014.

16. Cuffel C, Rivals JP, Zaugg Y, Salvi S, Seelentag W, Speiser DE, Liénard D, Monnier P, Romero P, Bron L and Rimoldi D: Pattern and clinical significance of cancer-testis gene expression in head and neck squamous cell carcinoma. Int J Cancer 128: 2625-2634, 2011.

17. Hartmann S, Meyer TJ, Brands RC, Haubitz IR, Linz C, Seher A, Kübler AC and Müller-Richter UD: MAGE-A expression clusters and antineoplastic treatment in head and neck cancer. Int J Mol Med 35: 1675-1682, 2015.

18. Hartmann S, Kriegebaum U, Küchler N, Brands RC, Linz C, Kübler AC and Müller-Richter UD: Correlation of MAGE-A tumor antigens and the efficacy of various chemotherapeutic agents in head and neck carcinoma cells. Clin Oral Investig 18: 189-197, 2014.

19. Hartmann S, Kriegebaum U, Küchler N, Lessner G, Brands RC, Linz C, Schneider T, Kübler AC and Müller-Richter UD: Efficacy of cetuximab and panitumumab in oral squamous cell carcinoma cell lines: Prognostic value of MAGE-A subgroups for treatment success. J Craniomaxillofac Surg 41: 623-629, 2013.

20. Han L, Jiang B, Wu H, Zhang S and Lu X: Expression and prognostic value of MAGE-A9 in laryngeal squamous cell carcinoma. Int J Clin Exp Pathol 7: 6734-6742, 2014.

21. Gu X, Fu M, Ge Z, Zhan F, Ding Y, Ni H, Zhang W, Zhu Y, Tang X, Xiong L, et al: High expression of MAGE-A9 correlates with unfavorable survival in hepatocellular carcinoma. Sci Rep 4: 6625, 2014.

22. Hatiboglu G, Pritsch M, Macher-Goeppinger S, Zöller M, Huber J, Haferkamp A, Pahernik S, Wagener N and Hohenfellner M: Prognostic value of melanoma-associated antigen A9 in renal cell carcinoma. Scand J Urol 47: 311-322, 2013.

23. Xu X, Tang X, Lu M, Tang Q, Zhang H, Zhu H, Xu N, Zhang D, Xiong L, Mao Y and Zhu J: Overexpression of MAGE-A9 predicts unfavorable outcome in breast cancer. Exp Mol Pathol 97: 579-584, 2014.

24. Xu Y, Wang C, Zhang Y, Jia L and Huang J: Overexpression of MAGE-A9 is predictive of poor prognosis in epithelial ovarian cancer. Sci Rep 5: 12104, 2015.

25. Zhai X, Xu L, Zhang S, Zhu H, Mao G and Huang J: High expression levels of MAGE-A9 are correlated with unfavorable survival in lung adenocarcinoma. Oncotarget 7: 4871-4881, 2016.

26. Zhan W, Zhang Z, Zhang Y, Ma J, Wu T, Gu Y, Li Y and Yang J: Prognostic value of MAGE-A9 expression in patients with colorectal cancer. Clin Res Hepatol Gastroenterol 40: 239-245, 2016.

27. Remmele W and Stegner HE: Recommendation for uniform definition of an immunoreactive score (IRS) for immunohistochemical estrogen receptor detection (ER-ICA) in breast cancer tissue. Pathologe 8: 138-140, 1987 (In German).

28. Heo DS, Snyderman C, Gollin SM, Pan S, Walker E, Deka R, Barnes EL, Johnson JT, Herberman RB and Whiteside TL: Biology, cytogenetics, and sensitivity to immunological effector cells of new head and neck squamous cell carcinoma lines. Cancer Res 49: 5167-5175, 1989.

29. Cooper JS, Pajak TF, Forastiere AA, Jacobs J, Campbell BH, Saxman SB, Kish JA, Kim HE, Cmelak AJ, Rotman M, et al: Postoperative concurrent radiotherapy and chemotherapy for high-risk squamous-cell carcinoma of the head and neck. N Engl J Med 350: 1937-1944, 2004.

30. Bernier J, Domenge C, Ozsahin M, Matuszewska K, Lefèbvre JL, Greiner RH, Giralt J, Maingon P, Rolland F, Bolla M, et al: Postoperative irradiation with or without concomitant chemotherapy for locally advanced head and neck cancer. N Engl J Med 350: 1945-1952, 2004.

31. Figueiredo DL, Mamede RC, Proto-Siqueira R, Neder L, Silva WA Jr and Zago MA: Expression of cancer testis antigens in head and neck squamous cell carcinomas. Head Neck 28: 614-619, 2006 
32. Kerkar SP, Wang ZF, Lasota J, Park T, Patel K, Groh E, Rosenberg SA and Miettinen MM: MAGE-A is more highly expressed than NY-ESO-1 in a systematic immunohistochemical analysis of 3668 cases. J Immunother 39: 181-187, 2016

33. Lee KD, Lee HS, Kim SW, Park T, Hong JC, Chang HK, Jung SB, Jeon $\mathrm{CH}$ and Park JW: Clinical significance of melanoma-associated antigen A1-6 expression in sputum of patients with squamous cell carcinoma of the larynx and hypopharynx. Head Neck 38 (Suppl 1): E736-E740, 2016.

34. Ries J, Agaimy A, Vairaktaris E, Kwon Y, Neukam FW, Strassburg LH and Nkenke E: Evaluation of MAGE-A expression and grade of dysplasia for predicting malignant progression of oral leukoplakia. Int J Oncol 41: 1085-1093, 2012.

35. Marcar L, Maclaine NJ, Hupp TR and Meek DW: Mage-A cancer/testis antigens inhibit p53 function by blocking its interaction with chromatin. Cancer Res 70: 10362-10370, 2010.

36. Monte M, Simonatto M, Peche LY, Bublik DR, Gobessi S, Pierotti MA, Rodolfo $M$ and Schneider C: MAGE-A tumor antigens target p53 transactivation function through histone deacetylase recruitment and confer resistance to chemotherapeutic agents. Proc Natl Acad Sci USA 103: $11160-11165,2006$

37. Yang B, O'Herrin SM, Wu J, Reagan-Shaw S, Ma Y, Bhat KM, Gravekamp C, Setaluri V, Peters N, Hoffmann FM, et al: MAGE-A, mMage-b, and MAGE-C proteins form complexes with KAP1 and suppress p53-dependent apoptosis in MAGE-positive cell lines. Cancer Res 67: 9954-9962, 2007.

38. Hartmann S, Zwick L, Scheurer MJJ, Fuchs AR, Brands RC, Seher A, Böhm H, Kübler AC and Müller-Richter UDA: MAGE-A11 expression contributes to cisplatin resistance in head and neck cancer. Clin Oral Investig: Oct 15, 2017 (Epub ahead of print).

39. Picard V, Bergeron A, Larue $\mathrm{H}$ and Fradet Y: MAGE-A9 mRNA and protein expression in bladder cancer. Int J Cancer 120 2170-2177, 2007
40. Wischnewski F, Pantel K and Schwarzenbach H: Promoter demethylation and histone acetylation mediate gene expression of MAGE-A1, -A2, -A3, and -A12 in human cancer cells. Mol Cancer Res 4: 339-349, 2006

41. Cacan E, Greer SF and Garnett-Benson C: Radiation-induced modulation of immunogenic genes in tumor cells is regulated by both histone deacetylases and DNA methyltransferases. Int J Oncol 47: 2264-2275, 2015.

42. Gao J, Aksoy BA, Dogrusoz U, Dresdner G, Gross B, Sumer SO, Sun Y, Jacobsen A, Sinha R, Larsson E, et al: Integrative analysis of complex cancer genomics and clinical profiles using the cBioPortal. Sci Signal 6: pl1, 2013.

43. Cerami E, Gao J, Dogrusoz U, Gross BE, Sumer SO, Aksoy BA, Jacobsen A, Byrne CJ, Heuer ML, Larsson E, et al: The cBio cancer genomics portal: An open platform for exploring multidimensional cancer genomics data. Cancer Discov 2: 401-404, 2012.

44. Yan Y, Hein AL, Etekpo A, Burchett KM, Lin C, Enke CA, Batra SK, Cowan KH and Ouellette MM: Inhibition of RAC1 GTPase sensitizes pancreatic cancer cells to $\gamma$-irradiation. Oncotarget 5: 10251-10270, 2014.

45. Skvortsov S, Jimenez CR, Knol JC, Eichberger P, Schiestl B, Debbage P, Skvortsova I and Lukas P: Radioresistant head and neck squamous cell carcinoma cells: Intracellular signaling, putative biomarkers for tumor recurrences and possible therapeutic targets. Radiother Oncol 101: 177-182, 2011.

46. Skvortsov S, Dudás J, Eichberger P, Witsch-Baumgartner M, Loeffler-Ragg J, Pritz C, Schartinger VH, Maier H, Hall J, Debbage $\mathrm{P}$, et al: Rac1 as a potential therapeutic target for chemo-radioresistant head and neck squamous cell carcinomas (HNSCC). Br J Cancer 110: 2677-2687, 2014. 